\title{
WORK GLOVES
}

\section{COMMERCIAL STANDARD CS139-47}

Effective Date for New Production from March 6, 1947

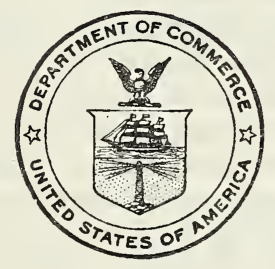

A RECORDED VOLUNTARY STANDARD OF THE TRADE

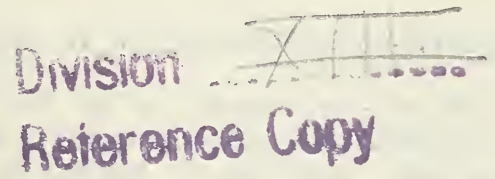

- UNITED STATES DEPARTMENT OF COMMERCE

W. AVERELL HARRIMAN, Secretary 


\section{COMMERCIAL STANDARDS}

Commercial Standards are voluntary standards of the trade developed through concerted action of those directly concerned, and issued by the U. S. Department of Commerce upon written evidence of their acceptability to the trade. They are initiated by written request from a responsible element of business to the Division of Trade Standards of the National Bureau of Standards. The Division of Trade Standards acts as a coordinating and fact-finding agency in ascertaining the desires of all concerned.

The Federal Government exercises no regulatory authority in the enforcement of Commercial Standards. In accepting a Commercial Standard, the producer, distributor, or user says in effect that he considers it a useful standard of practice, and plans to utilize it as far as practicable in his business, reserving the right to depart from the standard so long as no deception results from such departure. When reference to a Commercial Standard is made in contracts, labels, invoices, or advertising literature, however, the provisions of the standard are enforcible through usual legal channels as a part of the sales contract.

Organized in 1927, the Division of Trade Standards has assisted many industries in the development of Commercial Standards for a wide variety of commodities. A list of previously established Commercial Standards appears herein.

\section{COMMERCIAL STANDARD FOR WORK GLOVES}

On June 25,1946, at the instance of the Work Glove Institute, a Recommended Commercial Standard for Work Gloves was presented to interested producers, distributors, testing laboratories, and users for written acceptance. Those concerned have since accepted and approved the Commercial Standard as shown herein.

Project Manager: L. R. Gilbert, Division of Trade Standards, National Bureau of Standards.

Technical Adviser: E. L: Wallace, Division of Organic and Fibrous Materials, National Bureau of Standards. 
TS -4476

October 15, 1947

SUPPIFIMIIT

TO

WCRI GLOVES

\section{CQNERCIAI STANDARD CS139-47}

Elastic straps are now permissible across the backs of the gloves indicated in the following tables of CS139-47, and may be included at the option of the manufacturer.

SCFUDUIS A

\section{Pape 3 - Table 1 \\ Band top Ten's 10 ounce only "Women's 8 ounce}

Pape 3 - Table 2

Safety cuff

Gaunt Iet

Page 4 - Table 5

Safety cuff

Pape 5 - Table 3/1

Band top style
Pape 5 - Table 10

All types

Pape 6-Table 12

Safety cuff

Gauntlet

Page 6 - Table 13/1

All types

Page 7-Mebles 14 \& 15

A11 types

Page 7-Table 16

Gunil Pattern 



\section{WORK GLOVES}

\section{COMMERCIAL STANDARD CS139-47 PURPOSE}

1. The purpose of this commercial standard is to establish standard definitions, nomenclature, methods of measuring, and standard minimum measurements for work gloves, and to designate the types of work gloves and mittens that may be manufactured to the best economic interest of all concerned, including consumers, manufacturers, and distributors.

\section{SCOPE}

2. The standard covers work gloves and mittens made from canton flannel, jersey cloth, and fabric-leather combinations for men, women, and children. It includes quality requirements for fabric and fabricleather combination gloves and specifies classes, including types or styles.

\section{APPLICATION}

3. The requirements of this standard are applicable to finished gloves as delivered by the manufacturer.

\section{DEFINITIONS AND NOMENCLATURE ${ }^{1}$}

\section{Fabric.}

4a. Weight of fabric.

$4 \mathrm{a}(1)$. Canton flannel.-Where weight of canton flannel is specified in ounces it means ounces per linear yard, based on a fabric 34 inches wide.

$4 a(2)$. Jersey cloth. - Where the weight of jersey cloth is specified in ounces, it means ounces per square yard of fabric.

5. Gauntlet.-The word "gauntlet" as used in this standard shall mean that part of a gauntlet-type glove that extends from turtle neck or wrist seam along the wrist to upper end of glove.

6. Minimum measurements.- "Minimum measurements" mean the least dimensions to which specified types of gloves and mittens may be made.

7. Work gloves and mittens.-Work gloves and.mittens covered in this standard are made of canton flannel, jersey cloth, and fabricleather combinations, designed primarily for use in connection with manual effort as distinguished from gloves and mittens generally used for dress wear or protection against the elements. These gloves and mittens are customarily classified as men's, women's, and children's.

1 All terms used in this standard shall have their usual and customary trade meaning unless otherwise indicated. 


\section{GENERAL REQUIREMENTS}

8. Gauntlets and safety cuffs. ${ }^{2}$-Double- (2-ply) thickness fabrics for gauntlets and safety cuffs shall bè not less than a combination of materials specified in paragraphs $8 \mathrm{a}$ and $8 \mathrm{~b}$.

8a. Covering material. -2.85 yards 37 -inch twill ( $5.45 \mathrm{oz}$ per sq yd), or 6-ounce 37 -inch flannel (5.84 oz per sq yd).

8b. Lining materials. - 2.95 yards 36 to 37 inch osnaburg (5.27 to $5.42 \mathrm{oz}$ per sq yd), or 3 yard duck; or similar covering and lining materials of equivalent quality and value.

8c. Water-resistant materials.-Water-resistant material when used in the production of gauntlets and safety cuffs shall be of standard quality, weighing not less than 23 ounces per square yard, and shall be treated with a substance that will decrease substantially its water permeability for a reasonable period of time.

$8 c$ (1). In marking or stamping gauntlets or cuffs to indicate that they are "water resistant", the word "cuff" shall follow immediately with equal conspicuousness the words "Water resistant" and shall otherwise be set up in such a way that the public may not be mislead into believing that the water-resistant quality applies to other parts of the glove, nor shall any mark or description be deceptive in any other respect.

9. Jersey cloth.-Jersey cloth when steamed and pressed to remove wrinkles and to bring it to a uniform width shall not be stretched to finish wider than the original mill width of the finished material.

10. Knit wrist.

10a. Length.- The finished length of knit wrists shall be not less than $2 \frac{1}{2}$ inches for men's gloves, and $2 \frac{1}{4}$ inches for women's, small women's, and children's gloves.

10b. Tubing.-Tubing for knit wrists shall be not lighter than:

$10 \mathrm{~b}$ (1). 12 yards per lb, 21/4-inch width for men's gloves.

$10 \mathrm{~b}$ (2). 15 yards per lb, 2-inch width for women's gloves.

$10 \mathrm{~b}$ (3). 17 yards per lb, $1 \frac{3 / 4}{4}$-inch width for small women's and children's gloves.

11. Turtle neck.-Where turtle neck is specified, the material used shall be not less than 10-ounce fabric.

12. Leather.

12a. Cattle or horsehide.-Side-split cattlehide or horsehide of equivalent weight and quality may be used interchangeably.

12b. Medium side-split leather.-Where side-split leather is specified, the minimum average weight of palm leather shall be not less than $2 \frac{1}{4}$ ounces nor more than 3 ounces per square foot.

12c. Heavy side-split leather.-Where heavy side-split leather is specified, the minimum average weight of palm leather shall be not less than 3 ounces per square foot.

12d. Split leather. - Where split leather is specified it means shoulders and other pound stock (except middle splits).

12e. Colors of leather.-Colors are optional and may be used interchangeably.

13. Packaging. Gloves and mittens shall be packaged in units of 12 pairs.

2 Materials may be combined by either quilting or processing. 
14. Work gloves shall not be labeled as conforming to this standard if produced or finished with:

(a) Thumb seam welts or welts at thumb-crotch seam, or thumb straps on other than side split leather or grain-leather constructions.

(b) Pairs tacked, stapled, or otherwise fastened together.

(c) Rider tickets.

(d) Imprints on hand portion other than manufacturers trade marks.

\title{
DETAIL REQUIREMENTS
}

15. The types, styles, and classes of work gloves covered by this standard, and that may be labeled as conforming thereto, are shown in schedule A.

16. It is recommended that no individual manufacturer produce more than 100 numbers from schedule $A$, tables 1 to 16 , inclusive.

\section{SCHEDULE A}

\section{Types, Styles, and Classes}

TABLE 1.-W hite canton-flannel gloves, single thickness

[M-375-1] a

\author{
Clute Pattern: \\ Knit wrist: \\ Men's: 6-8-10-12 ounce. \\ Men's extra large: 12 ounce. \\ Women's: 6-8-10 ounce. \\ Women's, small: 6 ounce. \\ Band top: \\ Men's: $8-10-12$ ounce. \\ Women's: 8 ounce. \\ Gauntlet. Double (2-ply) thickness: \\ Men's: 10 ounce, without turtle neck. \\ Men's: 12 ounce, with or without turtle neck. \\ GunN or Fourchette Pattern: \\ Knit wrist: \\ Men's: 8-10-12 ounce. Standard thumb. \\ Men's: 8-10 ounce. Reversible thumb. \\ Gauntlet: Double (2-ply) thickness: \\ Men's: 10 ounce, without turtle neck. \\ Men's: 12 ounce, with or without turtle neck.
}

a This designation and similar designations under table headings refer to Conservation Order M-375 and to the tables therein.

TABLE 2.-Canton-flannel gloves with double-thickness 18-ounce nap-out palm and single-thickness back ${ }^{b}$

[M-375-2]

Knit wrist:

Men's: 8-ounce stripe back or 10-ounce white back.

Women's: 8-ounce stripe back or 10-ounce white back.

Safety cuff. Double (2-ply) thickness:

Men's: 8-ounce stripe back or 10-ounce white back, with or without turtle neck.

Gauntlet. Double (2-ply) thickness:

Men's: 8-ounce stripe back or 10-ounce white back, with or without turtle neck.

a The weights refer to Canton flannel only.

b Double parts may be quilted or processed. 


\section{TABLE 3."-Hot-mill canton-flannel gloves, nap-out palm}

[M-375-3]

\section{Quilted Palm: ${ }^{b}$}

Knit wrist:

Men's: 12-ounce palm, 12-ounce lining, 12-ounce back, 10-ounce knuckle strap. Inseam.

Band top:

Men's: 12-ounce palm and pull, 12-ounce lining, 12-ounce back, 12-ounce band, 10-ounce knuckle strap. Inseam.

Men's: 12-ounce palm without pull, 12-ounce lining, 12-ounce back, 12 - ounce band, 10-ounce knuckle strap. Inseam.

Men's: 12-ounce palm and pull, 12-ounce lining, 12-ounce back, 12-ounce band, 10-ounce knuckle strap. Outseam.

Gauntlet. Double (2-ply) thickness cuff:

Men's: 12-ounce palm and pull, 12-ounce lining, 12-ounce back, 10-ounce knuckle strap. Inseam.

Men's: 12-ounce palm without pull, 12-ounce lining, 12-ounce back, 10ounce knuckle strap. Inseam.

a The weights refer to Canton flannel only.

b Two-ply palm parts quilted only. In addition to the above, band-top inseam may be produced nap-in palm on special order, only when necessary for specific occupational requirements.

TABLE 4." White-flannel gloves, with double-thickness palm ${ }^{\mathrm{b}}$ and single-thickness back, nap-in

\section{$[\mathrm{M}-375-4]$}

Knit wrist:

Men's: 18-ounce palm, 10-ounce back.

Band top:

Men's: 18-ounce palm, 10-ounce back.

Gauntlet. Double-(2-ply) thickness cuff:

Men's: 18-ounce palm, 10-ounce back.

a The weights refer to white flannel only.

b Two-ply parts quilted only.

TABLE 5. "-Double throughout, nap-out flannel "chore" gloves

\section{[M-375-5]}

Quilted or Processed:

Knit wrist:

Men's: $12 \frac{1}{2}-14-14 \frac{1}{2}-16-18$ ounce.

Men's extra large: $12 \frac{1}{2}-14-14 \frac{1}{2}-16-18$ ounce.

Women's: $121 / 2-14-14 \frac{1}{1} 2-16$ ounce.

Safety cuff. Double (2-ply) thickness:

Men's: $12 \frac{1}{2}-14-14 \frac{1}{2}-16$ ounce.

\& The weights refer to the fabric only. 
TABLE 6.-Gunn or fourchette pattern, two-thumb, knit wrist, nap-out canton flannel husking gloves, single thrckness, white only, unless otherwise specified

[M-375-6]

Knit wrist:

Men's: 8-10-12 ounce.

Women's: $8-10$ ounce.

Men's: 12-ounce palm and thumb, with 8-ounce white or colored outside thumb patch.

Men's: 12-ounce palm, 12-ounce white or colored double throughout thumb, with 8-ounce liner.

TABLE 7.-Two-thumb, welt-seam, single-thickness, nap-out canton flannel back and palm, knit-wrist husking mittens

[M-375-7]

Knit wrist:

Men's: 12-ounce palm and thumb, 6-ounce thumb reinforcement.

Men's: 12-ounce palm and thumb with 8-ounce white or colored outside thumb patch.

Women's: 10-ounce palm and thumb, 6-ounce thumb reinforcement.

TABLE 8.- "Chore", smelters', and tick mittens

[M-375-8]

KNIT WRIST:

A. Chore mittens: Men's, $14 \frac{1}{2}, 16$, or 18 ounce, double throughout, nap-out canton flannel.

B. Smelters' mittens, open top: Men's, 20 ounce, double throughout, canton flannel.

C. Tick mittens: Men's, 61/2, 8-ounce tick shell or 8-ounce flannel shell, fleece-lined, with or without cotton wadding.

TABLE 8/1.-Women's industrial, gardening, and household gloves

[M-375-8/1]

Band-top style:

Women's, double-nap cloth. One size only.

TABLE 9.-Jersey gloves, single thickness

[M-375-9]

Knit wrist:

Men's: $9-101 / 2-13$ ounce, plain.

Women's: $9-10 \frac{1}{2}$ ounce, plain.

Women's, small: 9 ounce, plain.

TABLE 10.-Full-lined open-wrist slip-on jersey gloves

[M-375-10]

Open wrist:

Men's: 8-ounce plain shell, 51/2- to 6-ounce lining.

Men's: Extra-large, 8-ounce plain shell, 51/2- to 6-ounce lining.

Women's: 8-ounce fleece-in or fleece-out, plain shell, not more than three colors assorted, $5 \frac{1}{2}$ - to 6 -ounce lining. 
TABLE 11.-Children's single-thickness jersey gloves and mittens [M-375-11]

Gloves:

Knit wrist:

Children's: Ages up to 15:9 ounce, plain; not more than three colors assorted. Gauntlet:

Children's: Ages up to 15: 9 ounce, plain.

\section{Mittens:}

Knit wrist:

Children's: Ages up to 15:9 ounce, plain; not more than three colors assorted.

TABLE 12.-Leather-combinaiion gloves, without tips, 8-ounce canton-flannel back; 5 -ounce or heavier palm lining, not more than $3 / 4$ leather thumb

[M-375-12]

Clute Pattern:

Knit wrist:

Men's: Lined split-leather palm.

Women's: Lined split-leather palm.

Safety cuff, single ply:

Men's: Lined split-leather palm.

Gauntlet, single ply:

Men's: Lined split-leather palm.

Women's: Lined split-leather palm.

TABLE 13.-Leather-combination gloves, knit wrist, finger tips, 8-ounce flannel back, 6-ounce or heavier palm lining

[M-375-13]

Gunn Pattern:

Knit wrist:

Men's, A. Lined split leather, 3/4 thumb.

B. Lined side-split leather, medium or heavy weight, $3 / 4$ thumb.

C. Lined heavy side-split leather. Full leather thumb, forefinger, and little finger; separate wrist pull; with or without fulllength thumb strap (for loggers and lumbermen).

D. Lined heavy side-split leather. Full leather thumb and forefinger.

E. Lined side-split leather. Medium or heavy weight, $3 / 4$ thumb. 10\%2-ounce plain jersey back.

TABLE 13/1.-Leather-combination gloves, double-, two-ply, thickness gauntlet and safety cuff, finger tips, 8-ounce flannel back; 6-ounce or heavier palm lining

[M-375-13/1]

Gonn Pattern:

Gauntlet:

Men's: Lined split-leather, 3/4 thumb.

Safety cuff:

Men's: Lined split-leather $3 / 4$ thumb. 
TABLES 14 and 15.-Leather-combination gloves, water-resistant gauntlet, and safety cuff, finger tips, 8-ounce flannel back; 6-ounce or heavier palm lining

[M-375-14 and 15]

GunN Pattern:

Men's A. Lined split leather, $3 / 4$ thumb.

B. Lined split leather, $3 / 4$ thumb, with pull and knuckle straps.

C. Lined side-split leather, medium or heavy weight, with pull and knuckle straps, full leather thumb.

D. Lined side-split leather, medium or heavy weight, with pull and knuckle straps, full leather thumb and forefinger.

E. Lined side-split leather, medium or heavy weight, with pull, full leather thumb and forefinger; $7 / 8$-length leather back.

F. Lined grain leather, full leather thumb and forefinger, pull and knuckle straps.

G. Lined heavy side-split leather with pull, full leather thumb and forefinger; $3 / 4$-length leather back.

Women's: A. Lined side-split leather, $3 / 4$ thumb.

a B (C). Lined side-split leather, medium or heavy weight, with pull and knuckle straps, full leather thumb.

Gunn or Clute Pattern:

Men's: A (H). Lined heavy side-split leather palm. Full leather fingers, thumb, pull, and knuckle straps.

- Letters in parentheses relate to the reference letters in tables 14 and 15 of M-375.

TABLE 16.-Leather combination gloves, slip-on or drivers style, fingers tipped, full leather thumb, with or without draw strap on back

[M-375-16]

GunN Pattern:

Men's: Side-split or horse split leather, 8-ounce back.

\section{DETAIL REQUIREMENTS}

\section{METHOD OF MEASURING}

17. Length of glove.-Measured from wrist seam to end of second finger.

18. Width of palm.-Measured across palm just below thumb crotch.

19. Knit wrist length.-Measured from the wrist seam.

20. Length of gauntlet.-Measured from the turtle neck or wrist seam to end of gauntlet.

21. Width of gauntlet.

21a. Top.-Measured across top of gauntlet when it is laid out flat.

21b. Bottom.-Measured across gauntlet at point where it joins the body of the glove when the gauntlet is laid out flat.

22. Safety cuff, length.-Measured from turtle neck or wrist seam.

23. Wrist band, length.-Measured from wrist seam.

\section{SCHEDULE B}

\section{STANDARD MEASUREMENTS}

24. The standard measurements of various types of work gloves are shown in table 17. 
TABLE 17.-Standard measurements for work gloves

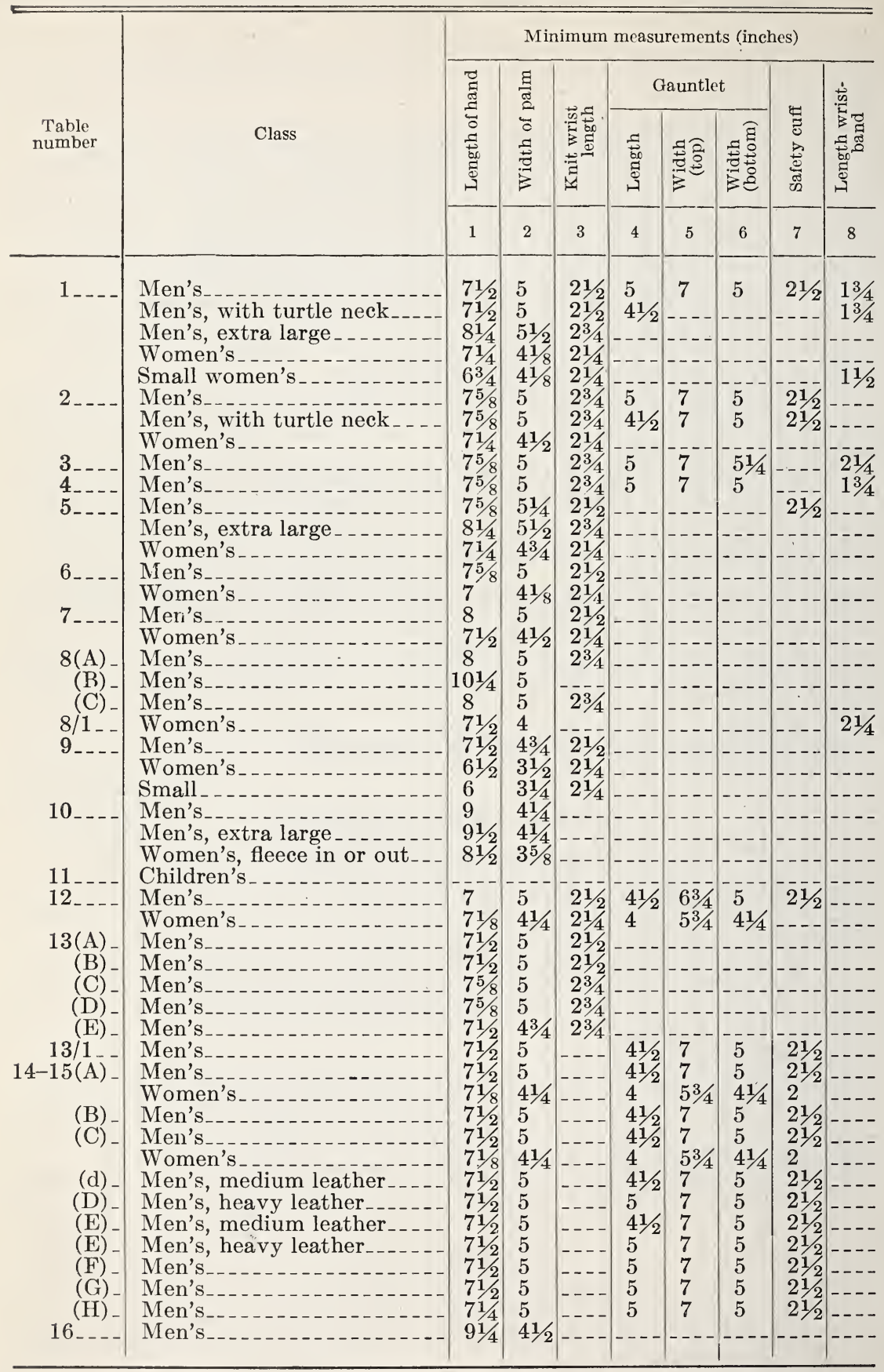




\section{LABELING}

25. Guarantee of compliance.-In order that purchasers may be assured that the work gloves they purchase comply with the applicable requirements of this standard, it is recommended that the following guarantee statement be included in manufacturers' labels, invoices, contracts, sales literature, etc.

The manufacturer guarantees that these gloves comply with the requirements of Commercial Standard CS139-47, as issued by the National Bureau of Standards of the United States Department of Commerce.

\section{EFFECTIVE DATE}

26. The standard is effective for new production from March 6, 1947.

\section{STANDING COMMITTEE}

27. The following individuals comprise the membership of the standing committee, which is to review prior to circulation for acceptance, revisions proposed to keep the standard abreast of progress. Comment concerning the standard and suggestions for revision may be addressed to any member of the committee or to the Division of Trade Standards, National Bureau of Standards, which acts as secretary for the committee.

George Lurie (chairman), Good Luck Glove Co., Carbondale, Ill. John E. Hunt, Fairfield Glove Co., Fairfield, Iowa.

Frederick F. Carothers, Riegel Textile Corporation, 342 Madison Avenue, New York 17, N. Y.

A. H. MAson, Wells Lamont Corporation, 1791 Howard Street, Chicago, Ill.

T. L. Blanke, National Retail Dry Goods Association, 100 West Thirty-first Street, New York, N. Y.

J. J. Schatz, Dept. 470, Spiegel, Inc., 1061 West Thirty-fifth Street, Chicago 9, IIl. (Representing Mail Order Association of America).

Lesser Segerman, S. Blechman \& Sons, Inc., 549-555 Broadway, New York, N. Y. (Representing the Wholesale Dry Goods Institute, Inc.)

Thомas A. Fernley, JR., The National Wholesale Hardware Association, 505 Arch Street, Philadelphia 6, Pa.

L. R. Seen, Borg \& Beck, Division Borg-Warner Corporation, 6558 South Menard Avenue, Chicago 38, Ill. (Representing National Association of Purchasing Agents)

Lloyd C. Halverson, The National Grange, 744 Jackson Place, Washington 6, D. C.

Raymond E. Steele, The National Fisheries Institute, 228 Victor Building, 724 Ninth Street, N. W., Washington 1, D. C.

\section{HISTORY OF PROJECT}

28. On November 29, 1945, the Work Glove Institute, Incorporated, at its annual meeting in Chicago, Ill., voted to request the cooperation of the National Bureau of Standards in establishing a commercial standard for work gloves, including requirements somewhat similar to those covered by Conservation order M-375 issued by the Civilian Production Administration.

29. Following receipt of this request by the Bureau, copies of a proposed commercial standard for work gloves were circulated to selected representatives of manufacturers, distributors, and consumers for advance comment. 
30. With the unqualified endorsement of a number of interested organizations, the recommended commercial standard for work gloves was submitted to the entire trade for written acceptance on June 25, 1946. Having received acceptances in writing estimated to represent a satisfactory majority, announcement was issued on January 6,1947 , that the standard would become effective for new production from March'6, 1947. 


\section{ACCEPTANCE OF COMMERCIAL STANDARD}

If acceptance has not previously been filed, this sheet properly filled in, signed, and returned will provide for the recording of your organization as an acceptor of this commercial standard.

\section{Date}

Division of Trade Standards,

National Bureau of Standards,

Washington 25, D. C.

Gentlemen:

We believe that the Commercial Standard CS139-47 constitutes a useful standard of practice, and we individually plan to utilize it as far as practicable in the

$\begin{array}{llll}\text { production }^{1} & \text { distribution }^{1} & \text { purchase }^{1} & \text { testing } \\ & \end{array}$

of work gloves.

We reserve the right to depart from it as we deem advisable.

We understand, of course, that only those articles which actually comply with the standard in all respects can be identified or labeled as conforming thereto.

Signature of authorized officer

(In ink)

(Kindly typewrite or print the following lines)

Name and title of above officer

Organization

(Fill in exactly as it should be listed)

Street address

City, Zone, and State

1 Underscore which one. Please see that separate acceptances are filed for all subsidiary companies and affiliates which should be listed separately as acceptors. In the case of related interests, trade associations trade papers, etc., desiring to record their general support, the words "General Support" should be added after the signature. 


\section{TO THE ACCEPTOR}

The following statements answer the usual questions arising in connection with the acceptance and its significance:

1. Enforcement.-Commercial standards are commodity specifications voluntarily established by mutual consent of those concerned. They present a common basis of understanding between the producer, distributor, and consumer and should not be confused with any plan of governmental regulation or control. The United States Department of Commerce has no regulatory power in the enforcement of their provisions, but since they represent the will of the interested groups as a whole, their provisions through usage soon become established as trade customs, and are made effective through incorporation into sales contracts by means of labels, invoices, and the like.

2. The acceptor's responsibility.-The purpose of commercial standards is to establish for specific commodities, nationally recognized grades or consumer criteria and the benefits therefrom will be measurable in direct proportion to their general recognition and actual use. Instances will occur when it may be necessary to deviate from the standard and the signing of an acceptance does not preclude such departures; however, such signature indicates an intention to follow the commercial standard where practicable, in the production, distribution or consumption of the article in question.

3. The Department's responsibility.-The major function performed by the Department of Commerce in the voluntary establishment of commercial standards on a Nation-wide basis is fourfold: first, to act as an unbiased coordinator to bring all interested parties together for the mutually satisfactory adjustment of trade standards; second, to supply such assistance and advice as past experience with similar programs may suggest; third, to canvass and record the extent of acceptance and adherence to the standard on the part of producers, distributors and users; and fourth, after acceptance, to publish and promulgate the standard for the information and guidance of buyers and sellers of the commodity.

4. Announcement and promulgation.-When the standard has been endorsed by a satisfactory majority of production or consumption in the absence of active, valid opposition, the success of the project is announced. If, however, in the opinion of the standing committee or the Department of Commerce, the support of any standard is inadequate, the right is reserved to withhold promulgation and publication. 


\section{ACCEPTORS}

31. The organizations listed below have individually accepted this standard for use as far as practicable in the production, distribution, testing, or purchase of work gloves and mittens. In accepting the standard they reserved the right to depart therefrom as they individually deem advisable. It is expected that articles which actually comply with the requirements of this standard in all respects will be regularly identified or labeled as conforming thereto, and that purchasers will require such specific evidence of conformity.

\section{ASSOCIATIONS}

(General Support)

American Retail Federation, Washington, D. C.

American Trucking Associations, Inc., Washington, D. C.

Building Officials Conference of America, Washington, D. C.

Cotton-Textile Institute, Inc.. The, New York, N. Y. Farm Bureau Coop. Association, Inc., Columbus, Ohio.

Grinding Wheel Manufacturers Association, Worcester, Mass.

Hardware Cloth \& Poultry Netting Institute, New York, N. Y.

National Founders Association, Chicago, Ill.

National Retail Dry Goods Association, New York, N. Y.

United Roofing Contractors Association, Chicago, Ill.

United States Pulp Producers Association, New York, N. Y

Work Glove Institute, Inc., Chicago, Ill.

Z. C. M. I. Wholesale Hardware Division, Salt Lake City, Utah.

\section{.FIRMS}

Ace Hardware Corp., Chicago, Ill.

A corn Glove Co., Inc., Palm, $\mathrm{Pa}$.

Alabama, State of, Montgomery, Ala.

Albany Hardware \& Iron Co., Albany, N. Y.

Amarillo Hardware Co., Amarillo, Tex.

American Wholesale Hardware Co., Long Beach, Calif.

Arnold, Nat S., San Francisco, Calif.

Askin Brothers Co., Inc., Baltimore, Md.

Associated Merchandising Corp., New York, N. Y.

A yres \& Co., L. S., Indianapolis, Ind.

B. B. Stores, Inc., Logansport, Ind.

Badger Paint \& Hardware Stores, Inc., Milwaukee, Wis.

Baird Hardware Co., Gainesville, Fla.

Bard Hardware Co., Reading, Pa.

Bartel Co., Adam H., Richmond, Ind.

Beck \& Gregg Hardware Co., Atlanta, Ga.

Billings Hardware Co., Billings, Mont.

Birmingham, City of, Birmingham, Ala.

Blish, Mize \& Silliman Hardware Co., Atchison, Kans.

Bon Marche, The, Seattle, Wash.

Boss Manufacturing Co., The, Kewanee, Ill.

Brewster \& Church Co., The, Chagrin Falls, Ohio.

Broadway Department Store, Inc., Los Angeles, Calif.

Brookville Glove Co., Brookville, Pa.

Brown Camp Hardware Co., Des Moines, Iowa.

Buckeye Glove Co., Toledo, Ohio.

Buhrman-Pharr Hardware Co., Texarkana, Ark.

Canton Hardware Co., The, Canton, Ohio.

Carlisle Hardware Co., Springfield, Mass.

Carolina Glove Co., Maiden, N. C.

Carpenter Hardware Co., The, Athens, Ohio.

Central Co-Operative Wholesale, Superior, Wis.

Centre Hardware Co., Roslindale, Mass.

Cloverdale Hardware \& Lumber Co., Cloverdale, Ind.
Colladay Hardware Co., The Frank, Hutchinson, Kans.

Colorado, State of, Department of Education, Denver, Colo.

Coppin Co., Inc., John R., Covington, Ky.

Corpus Christi Hardware Co., Corpus Christi, Tex

Crowley, Milner \& Co., Detroit, Mich.

D \& C Stores, Inc., Stockbridge, Mich.

Danner Brothers Co., Inc., Indianapolis, Ind.

Delta Haldware Co., Escanaba, Mich.

Denver Dry Goods Co., The, Denver, Colo.

Des Moines Glove \& Manufacturing Co., Inc., Des Moines, Iowa.

Dinkins-Davidson Hardware Co., Atlanta, Ga.

Donaldson Co., L. S., Minneapolis, Minn.

Duckwall Stores Co., The A. L., Abilenc, Kans.

Eagle Glove \& Garment Co., The, Muncie, Ind.

Eagle Stores Co., Inc., Charlotte, N. C.

Emery Industries, Inc., Cincinnati, Ohio.

Enoch Manufacturing Co., Mount Sterling, Ky.

Fairbanks, Morse \& Co., Beloit, Wis.

Fairficld Glove Co., Fairfield, Iowa.

Farm Burcau Services, Inc., Lansing, Mich.

Federal Hardware Co., New York, N. Y.

Field \& Co., Marshall, Chicago, nl.

Fishman Co., Inc., M. H., $5 \notin$ to $\$ 1.00$ Stores, New York, N. Y.

Florida State College for Women, School of Home Economics., Tallahassee, Fla. (General support.) Fones Brothers Hardware $\mathrm{C}_{0}$., Little Rock, Ark.

Frankfurth Hardware Co., Milwaukee, Wis.

Franklin Hardware \& Supply Co., Philadelphia, Pa.

Gates Hardware \& Supply Co., Tulsa, Okla.

General Hardware \& Supply Co., Philipsburg, $\mathrm{Pa}$

Gertz, Inc., B., Jamaica, N. Y

Glove Corp., The, Alexandria, Ind.

Good Luck Glove Co., Carbondale, Ill.

Grant, Inc., Gail G., Painesville, Ohio.

Craves-Humphreys Hardware Co., Roanoke, Va.

Green Co., H. L., New York, N. Y.

Griswold Co., The, Warren, Ohio.

Haines Supply \& Service, Inc., New York, N. Y.

Hall Hardware Co., Minneapolis, Minn.

Halle Brothers Co., The, Cleveland, Ohio.

Harco Hardware Co., Cleveland, Ohio.

Hasson-Bryan Hardware Co., Morristown, Tenn.

Hatch Textile Research, New York, N. Y.

Hayes Sammons Co., Mission, Tex.

Helena Hardware Co., Helena, Mont.

Henkle \& Joyce Wholesale Hardware Co., Lincoln, Nebr.

Huey \& Philp Hardware Co., Dallas, Tex.

Imperial Hardware Co., El Centro, Calif.

Industrial By-Products \& Research Co., Philadelphia, Pa.

Jackson Glove Manufacturing Co., The, Washington C. H. Ohio.

Jackson Hardware Co., Aberdeen, S. Dak.

Jacobs Glove Factory, Inc., Syracuse, N. Y.

Janesville Clothing Co., Janesville, Wis.

Jellico Hardwal e Co., Jellico, Tenn.

Jennison Hardware Co., The, Bay City, Mich

Johnston \& Larimer, Inc., Oklahoma City, Okla.. (general support).

Johnston \& Larimer, Inc., Wichita, Kans.

Joslin Company, F. N., Malden, Mass.

Kar Glove \& Apron Co., Detroit, Mich. 
Kaufman Store, Inc., The, Richmond, Va.

Kaul Glove \& Manufacturing Co., Detroit, Mich. Keller Glove Manufacturing Co., Plumsteadville, Pa.

Keller's Department Store, Liberty, N. Y.

Kelley How Thomson Company, Duluth, Minn.

Kelly Steel Works, Inc., Chicago, Ill.

King Hardwarc Co., Atlanta, Ga.

Klein Norton Co., Los Angeles, Calif.

Knoxville Glove Co., Knoxville, Tenn.

Kresge Co., S. S., Detroit, Mich.

Kruse Hardware Co., The, Cincinnati, Ohio.

Kugelman's, Woodsville, N. H.

Lake Erie Hardware Co., The, Cleveland, Ohio.

Lambert Manufacturing Co., Inc., Chillicothe, Mo.

Larson Hardware Co., Sioux Falls, S. Dak.

Latex Glove Manufacturing Co., Chicago, Ill. (general support)

Lazarus \& Co., F. \& R., Columbus, Ohio.

Lee Hardware Co., The, Salina, Kans.

Lee Hardware Co., Ltd., The, Shreveport, La.

Lilien Hardware \& Supply Corp., Long Island City, N. Y.

Los Angeles, City of, Los Angeles, Calif.

Mandel Brothers, Chicago, Ill.

Manhattan Gloves \& Notion Co., New York, N. Y.

Martins Ferry Glove Co., Uhrichsville, Ohio.

Merchants Cash Corp., B.oston, Mass.

Michigan State Purchasing Division, Lansing, Mich.

Miller Brothers Hardware Co., Richmond, Ind.

Miller \& Rhoads, Inc., Richmond, Va.

Model Glove Co., Greenville, Ill.

Montana Hardware Co., Butte, Mont. Montana Lumber \& Hardware Co., Lewistown,

Montgomery Ward, Chicago, Ill.

Morris Manufacturing Co., Newbern, Tenn.

Murphy Co., G. C., McKeesport, Pa.

Myers Brothers, Springfield, Ill.

National Glove Co., The, Columbus, Ohio.

Newberry's Hardware Co., Alliance, Nebr.

Newton Glove Manufacturing Co., Newton, N. C.

North Star Manufacturing Co., Tacoma, Wash.

Norton Hardware Co., Norton, Va.

Nusbaum Wholesale Hardware Co., San Francisco, Calif.

Odell Hiardware Co., Greensboro, N. C.

Ohio Valley Hardware \& Roofing Co., Evansville, Ind.

Oklahoma City Hardware Co., Oklahoma City, Okla.

O'Neill NcNamara Hardware Co., Vicksburg, Miss.

Pacific Department Store (formerly Pacific Outfitting Co.), Portland, Oreg.

Parker Co., M. L., Davenport, Iowa.

Peerless Glove Co., Inc., Grand Haven, Mich.

Penn Traffic Co., Johnstown, Pa.

Pennsylvania, Commonwealth of, Bureau of Standards, Dept. of Property \& Supplies, Harrisburg, $\mathrm{Pa}$

Pierce Glove Co., Inc., Chicago, Ill.

Pioneer Rubber Co., The, Willard, Ohio.

Pizitz Dry Goods Co., Louis, Birmingham, Ala.

Pomeroy's, Inc., Reading, Pa.

Pransky \& Sons, David, L, Philadelphia, Pa.

Priest Co., Van H., Madison, Fla.

Richmond Hardware Co., Richmond, Va.

Riegel Textile Corp., New York, N. Y.
Rike-Kumler Co., The, Dayton, Ohio.

Roanoke Hardware Co., Roanoke, Va.

Royal Glove Co., Royal Oak, Mich.

Saginaw Hardware Co., Saginaw, Mich.

San Jose Hardware Co., San Jose, Calif.

Schramm \& Schmieg Co., Burlington, Iowa.

Schudson, Inc., Chas., Milwaukee. Wis.

Schulte, Inc., D. A., New York, N. Y.

Schuneman's, Inc., St. Paul, Minn.

Sears, Roebuck \& Co., Chicago, Ill.

Seattle Glove Co., Seattle, Wash.

Segal \& Sons, M., Philadelphia, Pa.

Semer Hardware Co., Inc., New York, N. Y.

Shapleigh Hardware Co., St. Louis, Mo.

Sharp-Horsey Hardware Co., Atlanta, Ga.

Sherer Co., C. T., Worcester, Mass.

Silversteins, New Orleans, La.

Slattery Co., E. T., Boston, Mass.

Smith Brothers Hardware Co., The, Columbus, Ohio.

Smith Co., Timothy, Boston, Mass.

Snell, Inc., Foster D., Brooklyn, N. Y.

Southern Hardware Co., Charleston, W. Va.

Speer Hardware Co.. Fort Smith, Ark.

Spiegel, Inc., Chicago, Ill.

Sprouse-Reitz Co., Inc., Portland, Oreg.

Star Glove Co., Detroit, Mich.

Steinman Hardware Co., Lancaster, $\mathrm{Pa}$.

Sterling Stores Co., Little Rock, Ark.

Stichter Hardware Co., Inc., Reading, $\mathrm{Pa}$.

Stott \& Son Corp., Winona, Minn.

Stowe Hardware \& Supply Co., Kansas City, Mo.

Stratton-Warren Hardware Co., Memphis, Tenn.

Strevell-Paterson Hardware Co., Salt Lake City, Utah.

Strouss Hirshberg Co., The, Youngstown, Ohio.

Superior-Sterling Co., Bluefield, W. Va.

Tausche Hardware Co., V., La Crosse, Wis.

Tenk Hardware Co., Quincy, nl.

Tennessee Glove Co., Inc., Tullahoma, Tenn.

Texas Technological College, Division of Home Economics, Lubbock, Tex.

Toledo Glove Manufacturing Co., The, Toledo, Ohio. Towner Hard ware Co., Muskegon, Mich.

United Hardware \& Supply Co.. Titusville, Pa.

United StatfS Testing Co., Inc., Hoboken, N. J. (general support)

Universal Glove Cn., Toleo, Ohio.

Van Camp Hardware \& Iron Co., Indianapolis, Ind.

Wagner Hardware Co., The, Mansfield, Ohio.

Warlong Glove Manufacturing Co., Conover, N. C.

Washington State College, School of Home Econom: ics, Pullman, Wash (general support).

Wells Lamont Corp., Chicago, Ill.

White House Department Store, Tuscon, Ariz

Williams Brothers Corporation, Tulsa, Okla.

Wimberly \& Thomas Hardware Co., Inc., Birming. ham, Ala.

Woodruff Hardware Co., W. W., Knoxville, Tenn. Woodwell Co., Joseph, Pit tsburgh, Pa.

Woolworth Co., F. W., New York, N.Y.

\section{UNITED STATES GOVERNMENT}

Interior, U.S. Department of the, Washington, D.C. Justice Department, Federal Prison Industries, Inc.,

Federal Correctional Institution, Danbury, Conn. War Department, Washington, D. C. 


\section{COMMERCIAL STANDARDS}

CENo.

Item

$0-40$. Commercial standards and their value to business (third edition)

1-42. Clinical thermometers (third edition). 2-30. Mopsticks.

3-40. Stoddard solvent (third edition).

4-29. Staple porcelain (all-clay) plumbing fixtures.

5-46. Pipe nipples; brass, copper, steel and wrought-iron (second edition).

6-31. Wrought-iron pipe nipples (second edition). Superseded by CS5-46.

7-29. Standard weight mallcable iron or steel screwed unions.

8-41. Gage blanks (third edition)

9-33. Builders' template hardware (second edition).

10-29. Brass pipe nipples. Superseded by CS5-46.

11-41. Moisture regains of cotton yarns (second edition).

12-40. Fuel oils (fifth edition).

13-44. Dress patterns (fourth edition)

14-43. Boys' button-on waists, shirts, junior and sport shirts (made from woven fabrics) (third edition).

15-46. Men's pajama sizes (made from woven fabrics) (third edition).

16-29. Wall paper.

17-42. Diamond core drill fittings (third edition).

18-29. Hickory golf shafts.

19-32. Foundry patterns of wood (second edition).

20-42. Staple vitreous china plumbing fixtures (third edition).

21-39. Interchangeable ground-glass joints, stopcocks, and stoppers (fourth edition).

22-40. Builders' hardware (nontemplate) (second edition).

23-30. Feldspar.

24-43. Screw threads and tap-drill sizes.

25-30. Special serew threads. Superseded by CS24-43.

26-30. Aromatic red cedar closet lining.

27-36. Mirrors (second edition).

28-46. Cotton fabric tents, tarpaulins and covers (second edition)

29-31. Staple seats for water-closet bowls.

$30-31$. Colors for sanitary ware.

31-38. Wood shingles (fourth edition).

32-31. Cotton cloth for rubber and pyroxylin coating.

33-43. Knit underwear (exclusive of rayon) (second edition).

34-31. Bag, case, and strap leather.

35-47. Hardwood plywood (third edition)

36-33. Fourdrinier wire cloth (second edition).

37-31. Steel bone plates and screws.

38-32. Hospital rubber sheeting.

39-37. Wool and part wool blankets (second edition). (Withdrawn as commercial standard, July 14,1941 .

40-32. Surgeons' rubber gloves.

41-32. Surgeons' latex gloves.

42-43. Structural fiber insulating board (third edition).

43-32. Grading of sulphonated oils.

44-32. A pple wraps

45-45. Douglas fir plywood (sixth edition).

46-40. Hosiery lengths and sizes (third edition)

47-34. Marking of gold-filled and rolled-goldplate articles other than watchcases.

48-40. Domestic burners for Pennsylvania anthracite (underfeed type) (second edition).
CS No.

Item

49-34. Chip board, laminated chip board, and miscellaneous boards for bookbinding purposes.

50-34. Binders board for bookbinding and other purposes.

51-35. Marking articles made of silver in combination with gold.

52-35. Mohair pile fabrics (100-percent mohair plain velvet, 100-percent mohair plain frieze, and 50-percent mohair plain frieze).

53-35. Colors and finishes for cast stone.

54-35. Mattresses for hospitals.

55-35. Mattresses for institutions.

56-41. Oak flooring (second edition).

57-40. Book cloths, buckrams, and impregnated fabrics for bookbinding purposes except library bindings (second edition)

58-36. Woven elastic fabrics for use in overalls (overall elastic webbing).

59-44. Textiles-testing and reporting (fourth edition).

60-36. Hardwood dimension lumber.

61-37. Wood-slat venetian blinds.

62-38. Colors for kitchen accessories.

63-38. Colors for bathroom accessories.

64-37. Walnut veneers.

65-43. Methods of analysis and of reporting fiber composition of textile products (second edition).

66-38. Marking of articles made wholly or in part of platinum.

67-38. Marking articles made of karat gold.

68-38. Liquid hypochlorite disinfectant, deodorant, and germicide.

69-38. Pine oil disinfectant.

70-41. Phenolic disinfectant (emulsifying type) (second edition) (published with CS71-41).

71-41. Phenolic disinfectant (soluble type) (second edition) (published with CS70-41).

72-38. Household insecticide (liquid spray type).

73-45. Old growth Douglas fir standard stock doors (third edition)

74-39. Solid hardwood wall paneling.

75-42. Automatic mechanical draft oil burners designed for domestic installations (second edition)

76-39. Hardwood interior trim and molding.

77-40. Sanitary cast-iron enameled ware.

78-40. Ground-and-polished lenses for sun glasses (second edition) (published with CS79-40).

79-40. Blown, drawn, and dropped lenses for sun glasses (second edition) (published with CS78-40).

80-41. Electric direction signal systems other than semaphore type for commercial and other vehicles subject to special motor vehicle laws (after market).

81-41. Adverse-weather lamps for vehicles (after market).

82-41. Inner-controlled spotlamps for vehicles (after market)

83-41. Clearance, marker, and identification lamps for vehicles (after market).

84-41. Electric tail lamps for vehicles (after market).

85-41. Electric license-plate lamps for vehicles (after market).

86-41. Electric stop lamps for vehicles (after market).

87-41. Red electric warning lanterns. 
CS No. Item

88-41. Liquid-burning flares.

89-40. Hardwood stair treads and risers.

90- . (Reserved for power shovels and cranes).

91-41. Factory-fitted Douglas fir entrance doors.

92-41. Cedar, cypress and redwood tank stock lumber.

93-41. Portable electric drills (exclusive of high frequency).

94-41. Calking lead.

95-41. Lead pipe.

96-41. Lead traps and bends.

97-42. Electric supplementary driving and passing lamps for vehicles (after market).

98-42. Artists' oil paints.

99-42. Gas floor furnaces-gravity circulating type.

100-44. Porcelain-enameled steel utensils (second edition).

101-43. Flue-connected oil-burning space heaters equipped with vaporizing pot-type burners.

102- . (Reserved for Diesel and fuel-oil engines).

103-42. Cotton and rayon velour (jacquard and plain).

104-46. Warm-air furnaces equipped with vaporizing pot-type oil burners (second edition).

105-43. Mineral wool; loose, granulated, or felted form, in low-temperature installations.

106-44. Boys' pajam a sizes (woven fabrics) (second edition).

107-45. Commercial electric-refrigeration condensing units (second edition).

108-43. Treading automobile and truck tires.

109-44. Solid-fuel-burning forced-air furnaces.

110-43. Tire repairs-vulcanized (passenger, truck, and bus tires).

111-43. Earthenware (vitreous-glazed) plumbing fixtures.

112-43. Homegeneous 'fiber wallboard.

113-44. Oil-burning floor furnaces equipped with vaporizing pot-type burners

114-43. Hospitalsheeting for mattress protection. war conditions with a view toward early revision.

Noтіce.-Those interested in commercial standards with a view toward accepting them as a basis of everyday practice may secure copies of the above standards, while the supply lasts, by addressing the Division of Trade Standards, National Bureau of Standards, Washington 25, D. C.

\section{CS No.}

115-44. Porcelain-enameled tanks for domestic use.

116-44. Bituminized-fibre drain and sewer pipe.

117-44. Mineral wool; blankets, blocks, insulating cement, and pipe insulation for heated industrial equipment.

118-44. Marking of jewelry and novelties of silver.

(E) 119-45. Dial indicators (for linear measurements).

120-46. Standard stock ponderosa pine doors. (second edition)

121-45. Women's slip sizes (woven fabrics).

122-45. Western hemlock plywood.

123-45. Grading of diamond powder.

(E) 124-45. Master disks.

125-45. Prefabricated homes.

127-45. Self-contained mechanically refrigerated drinking water coolers.

128-45. Men's sport shirt sizes-woven fabrics (other than those marked with regular neckband sizes).

129-46. Materials for safety wearing apparel.

130-46. Color materials for art education in schools.

131-46. Industrial mineral wool products, all types-testing and reporting.

132-46. Hardware cloth.

133-46. Woven wire netting.

134-46. Cast aluminum cooking utensils (metal composition).

135-46. Men's shirt sizes (exclusive of work shirts).

136-46. Blankets for hospitals (wool, and wool and cotton). shorts (woven fabrics)

138-47. Insect wire screening.

139-47. Work gloves.

140-47. Convectors; testing and rating.

141-47. Sine bars, blocks, plates and fixtures.

1 Where (E) precedes the CS number, it indicates an emergency commercial standard, drafted under
war conditions with a view toward early revision.
126-45. Tank mounted air compressors.

137-46. Size measurements for men's and boys' 


\section{Reference book not to be taken from the Library. \\ October 15, 1947}

\section{SUPPLE AMTT \\ TO \\ ORI GIOVES}

COM GRCIAI STAMDADD CS733-47

Elastic straps are now permissible across the backs of gloves indicated in the following tables of CS139-47, and may be included at the option of the manufac turer.

\section{STFEDUIE A}

Pate 3 - Table 1

$$
\begin{aligned}
& \frac{\text { Sand top }}{\text { Men's } 10 \text { ounce only }} \\
& \text { Women's } 8 \text { ounce }
\end{aligned}
$$

Pcap $3-$ Table 2

Safety cuff

Gauntlet

\section{Page 4"-Table 5}

Safety cuff

Page 5 - Table $8 / 1$

Band top style
Page 5 - Ta.ble 10

\section{Al1 types}

Page 6-Table 12

Sefety cuff

Gauntlet

Page 6 - Table 13/1

A11 types

Page 7-Tables 14 \& 15

All types

Page 7-Table 16

Gunn Pattern 
